\title{
Conservation and habitat restoration of moorland and bog in the UK uplands: A regional, paleoecological perspective
}

Frank M. Chambers and John R.G. Daniell

Centre for Environmental Change and Quaternary Research, University of Gloucestershire, UK; fchambers@glos.ac.uk

\section{Regional paleoecological data can provide a wide range of possible restoration scenarios for degraded moorland and bog habitats.}

Conservation practice in the United Kingdom (UK) uplands has been strongly influenced by policy responses to the Convention on Biological Diversity (1992). The UK was the first nation to produce a national Biodiversity Action Plan (BAP) (Department for Environment, Food and Rural Affairs, 2007a,b; UKBAP, 2008); policy is now enshrined in Habitat Action Plans (65 HAPs), Species Action Plans (1149 SAPs) and Local Biodiversity Action Plans (innumerable LBAPs), plus European desig-

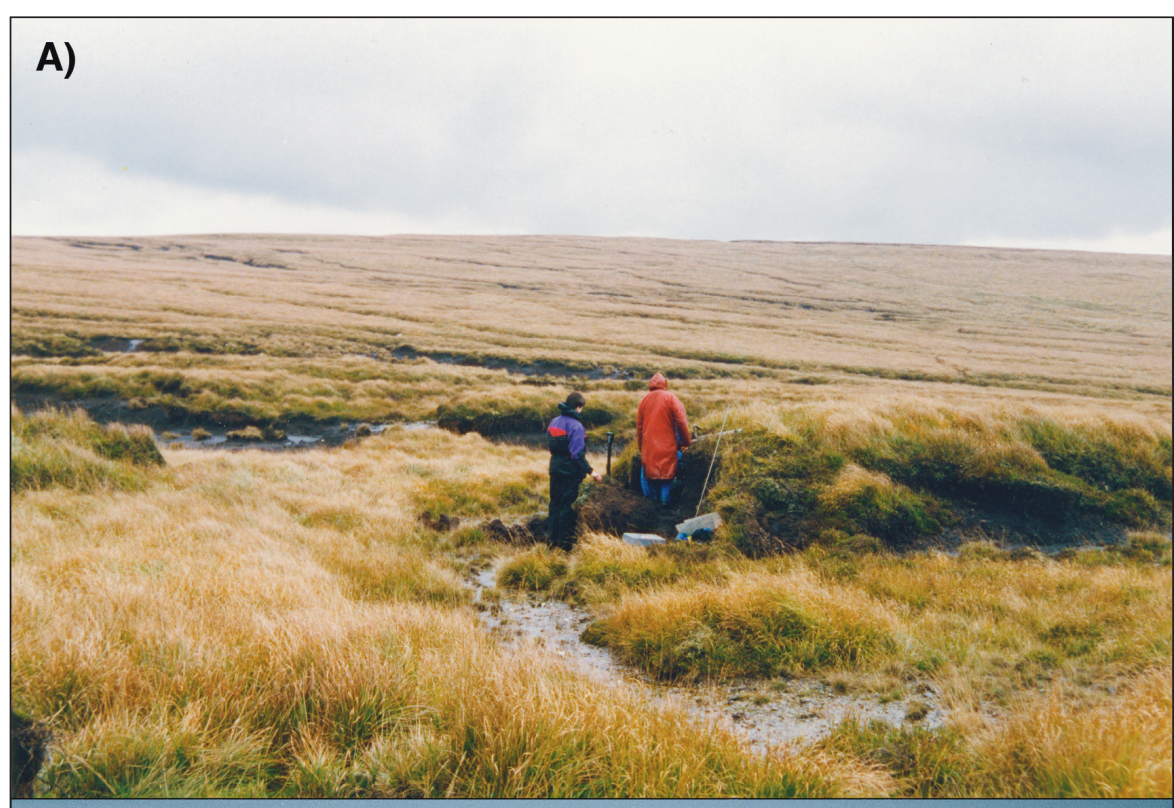

B)

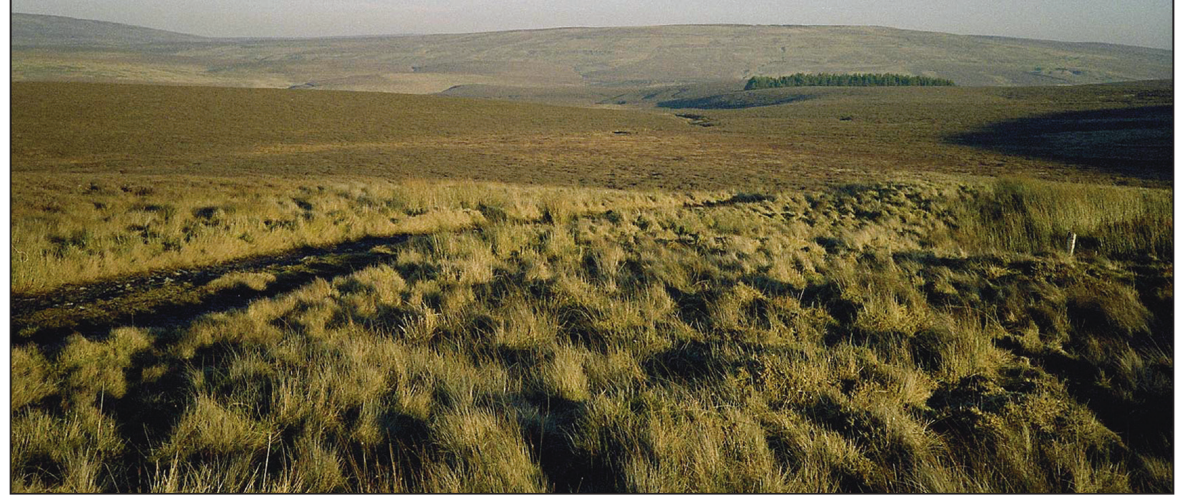

Figure 1: $\boldsymbol{A}$ ) Degraded mire and moorland landscape of Drygarn Fawr, Mid-Wales, dominated by Molinia caerulea (purple moor grass). B) Valley Bog, Moor House, Northern England. The Valley Bog core site (VB1: Fig. 2b) is located in the middle ground in heather moorland.

nations of Special Areas of Conservation (SACs) and possible candidates (cSACs). This plethora of acronyms has emerged since Ratcliffe's (1977) Nature Conservation Review, which focused on Sites of Special Scientific Interest (SSSIs) and National Nature Reserves (NNRs). Habitat Action Plans focus on arresting decline of diminishing habitats, restoring habitats to satisfactory condition and expanding the habitat cover where feasible (Jones et al., 2003). Implementation is devolved sepagued on grounds of biodiversity (following Bremer and Farley, 2010) that either economic coniferous forestry or amenity deciduous woodland would be legitimate objectives. However, if restoration of degraded moorland and blanket bog is the intention, this requires knowledge of the previous vegetation, specifically: how long it endured, which species are significantly reduced or extinct, which factors led to the claimed declines, whether those factors can be mitigated, and viable targets. Currently, restoration is predicated on decadal to sub-centennial survey data that show areal loss. For example, a $30 \%$ loss of or serious damage to blanket bog in Great Britain was estimated for the period from 1949 (when the Nature Conservancy Council was established) to the early 1980s (NCC, 1984; see also Usher and Thompson, 1988). This contrasts with thousands of years of cultural landscape history that preceded contemporary vegetation communities. Though emphasis is placed on restoration, few local conservation practitioners will be fully aware of past vegetation communities to which degraded habitats might be restored (see Hodder et al., 2009). Short-term targets and sub-decadal timescales dominate habitat restoration activity. Seldom is account taken of the millennial-scale development of upland ecosystems, shown by studies of long-term ecology (viz., paleoecology; Willis and Birks, 2006), which can be conducted on peat beneath moorland and bog vegetation (Chambers and Charman, 2004).

Favored vegetation types in the UK uplands, to which "restoration" is directed, include Sphagnum- (bog moss) dominat- 
ed blanket bog and heather moorland, for which the UK has the largest expanse. The former is widespread in the Flow Country of northern Scotland (Lindsay et al., 1988), but is now relatively rare in England, Wales and Northern Ireland, owing to atmospheric pollution, drainage, burning, peat extraction, over-grazing, and afforestation with exotic conifers. Tallis (1998) calculated that in the British Isles only $18 \%$ of heather moorland remained in natural or near-natural condition.

In the open uplands of England and Wales, large expanses of mire and moorland are occupied by the plant community Molinietum (Fig. 1A). Its vegetation provides poor grazing for sheep, which are now the principal domestic grazers. The dominant plant, Molinia caerulea (purple moor grass), is deciduous. As it has no foliage in winter and grows coarse, long stems in summer, its palatability for sheep is limited to the "spring bite". In Northern England it provides only limited cover for the economic "game" bird, Red Grouse, which is better suited to Callunetum-heather moorland (Fig. 1B) dominated by Calluna vulgaris (ling, or common heather)-a cultural landscape maintained by grazing (Stevenson and Thompson, 1993) and controlled burning.

In contrast to blanket bog, which is mainly prized for its conservation importance, heather moorland has both economic and amenity value. However, it saw a calculated loss of $23 \%$ in Scotland within four decades (NCC, 1984), partly attributed by Robertson et al. (2001) to lack of management of some grouse moors. Heather moorland is favorably regarded for its attractive appearance in summer and early autumn, particularly for visitors to upland National Parks. These include Exmoor, in Southwest England, for which heather moorland has totemic significance, but where Red Grouse is extinct. There, "swaling" (controlled burning) is used to maintain heather, but some areas have been lost to Molinia. Landscapes dominated by Molinia are monotonous and unattractive for visitors, having low amenity value, and are regarded as degraded (Yeo, 1997).

\section{Paleoecology informs restoration targets}

Conservation agencies have targets for degraded moorland habitats, with restoration envisaged to heather moorland or conceivably to Sphagnum-dominated bog. Experimental data indicate the relative efficacy of pony grazing, use of herbicides, and burning as agents of control of Molinia caerulea (Marrs et al., 2004). However, the timing and cause of the

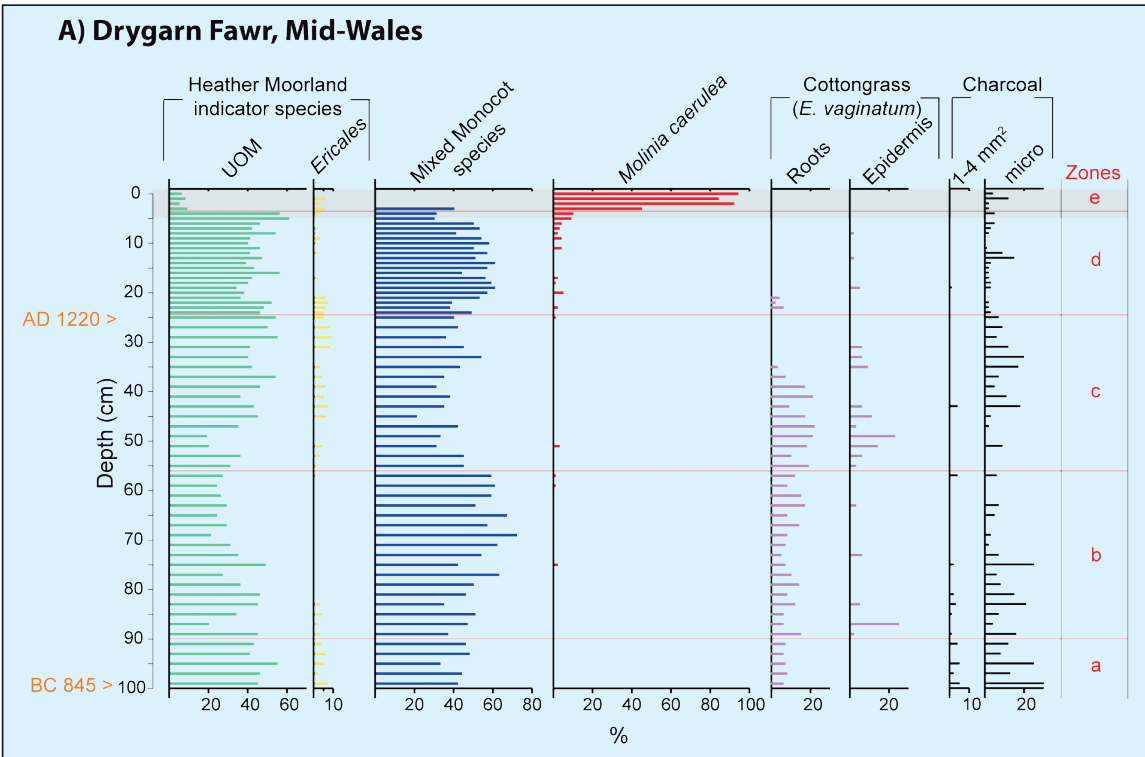

B) Valley Bog, Northern England

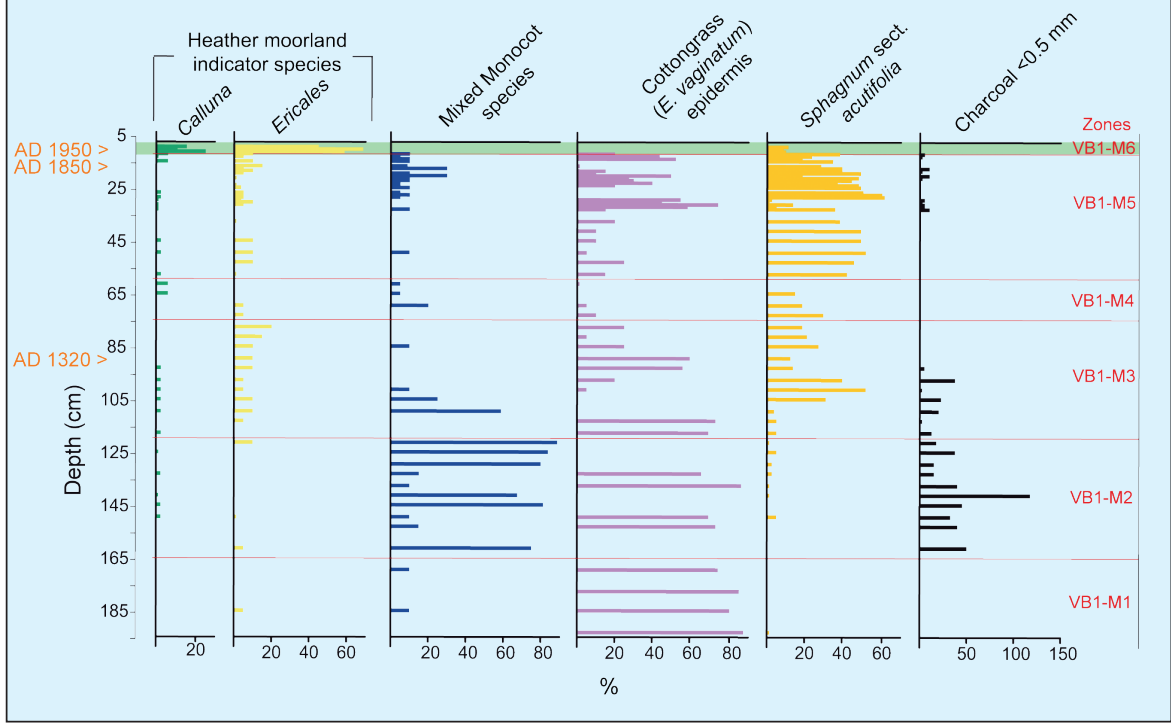

Figure 2: A) Dominant plant macrofossil abundances in a peat core from Drygarn Fawr, Mid-Wales (Chambers et al., 2007a). The rise in Molinia remains (red) occurs only after the Industrial Revolution (IR; estimated at C. AD 1900, gray shading). This rise was not caused by increased burning, as attested by no significant changes in the charcoal record at this time (black) but is likely the result of a change in grazing pressure and deposition of nitrogen following the IR. UOM: unidentified organic matter, which, in high abundance, may signify Calluna-dominated vegetation (e.g., Heather moorland). B) Dominant plant macrofossil abundances from Valley Bog, Moor House National Nature Reserve, Northern England. Heather moorland is present only in the most recent Zone (green shading, VB1-M6, characterized by abundant Ericales and Calluna vulgaris macrofossils), indicating that it has no longevity in this locality (unpublished data from Chambers et al., 2006). Timescales, calibrated to approximate calendar ages, compiled from record of spheroidal carbonaceous particles and radiometric dating $\left({ }^{210} \mathrm{~Pb} ;{ }^{14} \mathrm{C}\right)$.

overwhelming dominance of Molinia (variously attributed to overgrazing, lack of heather moorland management or uncontrolled burning) remained elusive until the initiation of paleoecological studies on a regional scale. Paleoecological data from Exmoor and Mid- and South Wales show the spread and expansion of Molinia only after the start of the Industrial Revolution. Importantly, the data also indicate multiple causes: not grazing pressure alone, but rather a change in the dominant grazer from cattle to sheep, nor burning alone, as Molinia has spread into areas without evidence of an increase in fire intensity or frequency (Fig. 2A; Chambers et al., 1999, $2007 a, b)$. Additionally it has been hypothesized that nitrogen deposition post-In- dustrial Revolution provided Molinia with a competitive advantage in a pastoral regime of unprecedentedly high stocking density of sheep (Chambers et al., 2007b). Plant macrofossil data show that, before high density stocking of sheep, Molinia was only a minor component of the regional flora (Chambers et al., 2007a).

\section{Regional significance of paleodata}

In habitat conservation practice for moorland and bogs, the emphasis is on restoring the health of plant communities defined in the National Vegetation Classification (NVC; e.g., Rodwell et al., 1991, 2000). The NVC survey of British vegetation was conducted by expert ecologists 
in the late $20^{\text {th }}$ century. However, as a "snapshot" of the then current vegetation, it can be criticized for lacking a sufficiently long-term perspective. Paleodata from South Wales and Northern England show the former presence of plant species regionally extinct as a result of human activity, including Sphagnum austinii (syn. S. imbricatum ssp. austinii) (McClymont et al., 2008, 2009), which was also a major peat former in raised bogs in England and Wales for thousands of years in the midlate Holocene (Hughes et al., 2007, 2008). Regional paleodata therefore imply that inter-regional translocation of key bog species could be justified as part of future habitat restoration. Moreover, paleoecological data of former plant communities show a wider range of possible restoration targets for Molinietum than is implied by the NVC, and so broaden the range of possible replacements. They also question the longevity of some Callunetum: its endurance in some parts of England and Wales has been shorter than generally thought (Fig. 2B; see also Chambers et al., 2007b).

Davies and Bunting (2010) argue there is an urgent need to "bridge the gap" between ecology and paleoecology. The latter has fundamental implications for the future practice of conservation and habitat management: regional paleoecological data question vegetation endurance, reveal regional declines, extinctions and their causes, and can help identify a range of viable restoration targets.

\section{References}

Chambers, F.M., Mauquoy, D. and Todd, P.A., 1999: Recent rise to dominance of Molinia caerulea in Environmentally Sensitive Areas: new perspectives from palaeoecological data, Journal of Applied Ecology, 26: 719-733.

Chambers, F.M., Mauquoy, D., Cloutman, E.W., Daniell, J.R.G. and. Jones, P.S., 2007a: Recent vegetation history of Drygarn Fawr (Elenydd SSSI), Cambrian Mountains, Wales: implications for conservation management of degraded blanket mires, Biodiversity and Conservation, 16: 2821-2846.

Davies, A.L. and Bunting, M.J., 2010: Applications of palaeoecology in conservation, The Open Ecology Journal, 3: 54-67.

McClymont, E.L., Mauquoy, D., Yeloff, D., Broekens, P., van Geel, B., Charman, D.J., Pancost, R.D., Chambers, F.M. and Evershed, R.P., 2008 The disappearance of Sphagnum imbricatum from Butterburn Flow, UK, The Holocene, 18: 991-1002.

Willis, K.J. and Birks, H.J.B., 2006: What is natural? The need for a longterm perspective in biodiversity conservation, Science, 314 1261-1265.

For full references please consult:

http://www.pages-igbp.org/products/newsletters/ref2011_2.pdf

\section{Spatial and temporal controls on hydro-geomorphic processes in the French Prealps}

\section{Darren S. Crook ${ }^{1}$, R.C. Chiverrell ${ }^{2}$, J.A. Dearing ${ }^{3}$, R.T. Jones ${ }^{4}$ and K.E. Welsh ${ }^{5}$}

'Division of Geography and Environmental Sciences, University of Hertfordshire, Hatfield, UK; D.Crook@herts.ac.uk ${ }^{2}$ Department of Geography, University of Liverpool, UK; ${ }^{3}$ Palaeoecology Laboratory, University of Southampton, UK; ${ }^{4}$ College of Life and Environmental Sciences, University of Exeter, UK; ${ }^{5}$ Department of Geography and Development Studies, University of Chester, UK

\section{Integration of paleoenvironmental reconstructions, environmental history and cellular modeling sheds light on the likely impacts of climate change on hydrological and geomorphological processes in the French Prealps.}

By the end of the $21^{\text {st }}$ century, IPCC reports (2007) suggest winter precipitation in European Alpine regions will increase by 10-20\% compared with 1980-1999, while summer precipitation will decrease by approximately $20 \%$. Here, we review findings

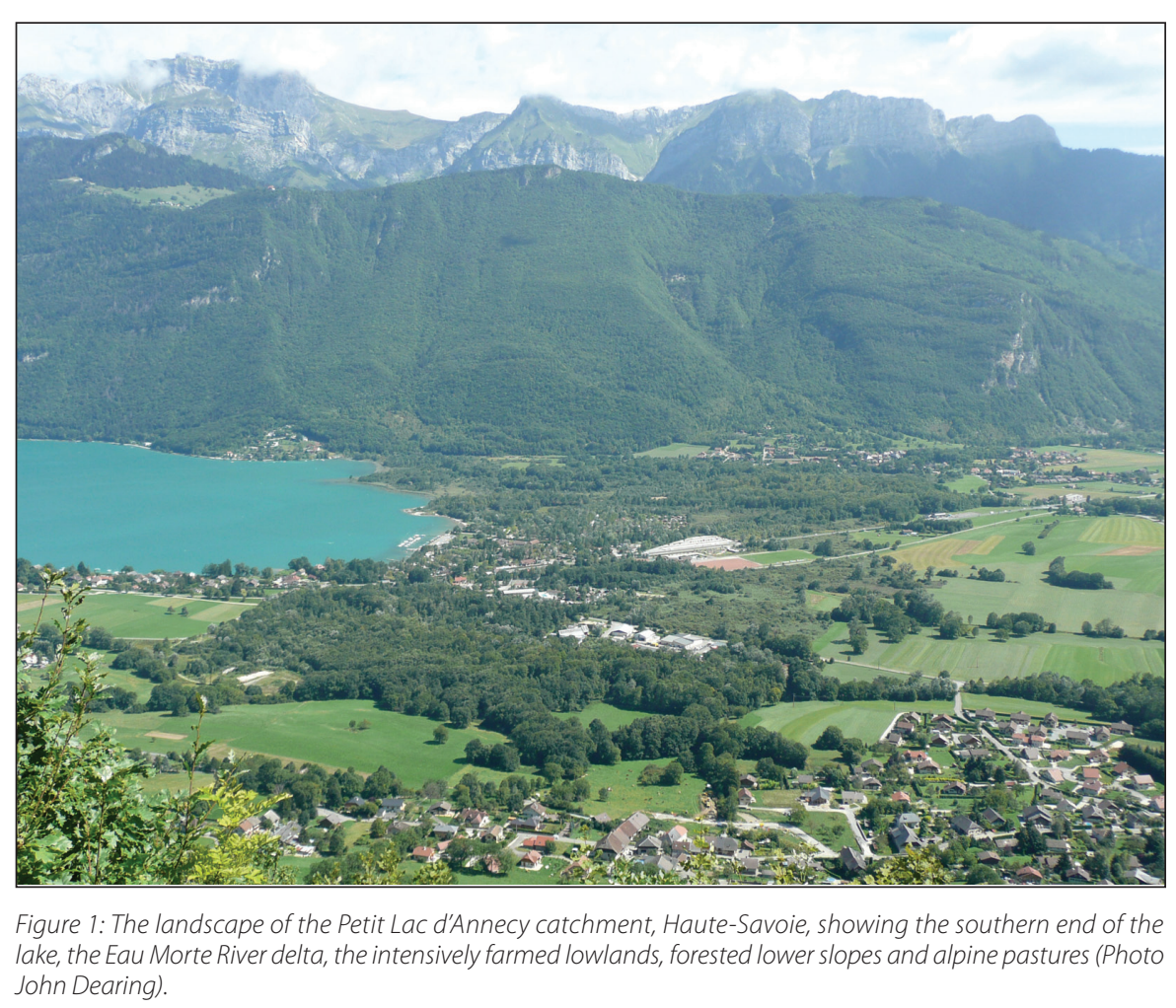

Figure 1: The landscape of the Petit Lac d'Annecy catchment, Haute-Savoie, showing the southern end of the lake, the Eau Morte River delta, the intensively farmed lowlands, forested lower slopes and alpine pastures (Photo John Dearing).

from research undertaken in the French Prealps in order to shed light on the implications of climate change for hydro-geomorphic processes. Over the past 20 years, the Annecy lake-catchment $\left(45^{\circ} 48^{\prime} \mathrm{N}\right.$, $\left.6^{\circ} 8^{\prime} \mathrm{E}\right)$ has provided the focus for a num- ber of studies, drawing on methods used in paleoecology, environmental history and process modeling, to investigate the links between human activities, climate and hydro-geomorphic processes. Lying at an altitude of $447 \mathrm{~m}$ asl in the prealps of Haute-Savoie, the lake comprises two basins, the Grand and Petit Lacs. Integration of data and models from mainly the Petit Lac and its catchment (Fig. 1) has generated significant insight into the spatiotemporal nature of human-environment interactions across the wider region.

\section{Paleoenvironmental reconstruction}

Foster et al. (2003) reconstructed the mechanisms of flooding and sediment transport within the Petit Lac catchment over timescales of months to centuries from lake and floodplain sediments that were representative of large catchment areas. Analysis of the results revealed that climate and land-use controls on the hydrological and sediment system were complex and varied according to the timescale of observation. In general, cycles of agricultural expansion and deforestation appeared to have been the major cause of shifts in the hydro-geomorphic system during the late Holocene. It was suggest- 